CLINICAL STUDY

\title{
Comparisons in the epidemiology, diagnostic features and cure rate by transsphenoidal surgery between paediatric and adult-onset Cushing's disease
}

\author{
H L Storr ${ }^{1}$, K I Alexandraki ${ }^{2}$, L Martin ${ }^{1}$, A M Isidori ${ }^{2}$, G A Kaltsas ${ }^{2}$, J P Monson ${ }^{2}$, G M Besser ${ }^{2}$, M Matson ${ }^{3}$, \\ J Evanson $^{3}$, F Afshar $^{4}$, I Sabin ${ }^{4}$, M O Savage ${ }^{1, *}$ and A B Grossman ${ }^{2, *}$ \\ Departments of ${ }^{1}$ Paediatric Endocrinology, ${ }^{2}$ Endocrinology, ${ }^{3}$ Radiology and ${ }^{4}$ Neurosurgery, Barts and The London School of Medicine and Dentistry, \\ London EC1A 7 BE, UK
}

(Correspondence should be addressed to H L Storr who is now at Barts and The London School of Medicine and Dentistry, William Harvey Research Institute, Centre for Endocrinology, John Vane Building, Charterhouse Square, London EC1M 6BQ, UK; Email: h.l.storr@qmul.ac.uk)

*(M O Savage and A B Grossman are considered as senior authors)

\begin{abstract}
Objective: There are few published comparisons between paediatric and adult-onset Cushing's disease (CD). We compare the epidemiology, diagnostic features and cure rate by transsphenoidal surgery (TSS) in these groups.

Design: Retrospective review of patient databases in a single university hospital centre.

Patients: Totally, 41 paediatric (mean age $12.3 \pm 3.5$ years; range 5.7-17.8) and 183 adult (mean age $40 \pm 13$ years; range 18.0-95.0) patients with CD were investigated.

Results: Paediatric CD was characterised by male (63\%) and adult CD by a female predominance (79\%, $P<0.0001)$. There were small but significant differences in clinical presentation. Biochemical features of CD were comparable except the serum cortisol increase during a $\mathrm{CRH}$ test: mean change (105\%, $n=39)$ in paediatric and $(54 \%, n=123)$ in adult subjects $(P<0.0001)$. Macroadenomas were more common in adult $(15 \%, 28 / 183)$ than in paediatric $(2 \%, 1 / 41, P=0.04) \mathrm{CD}$. Corticotroph microadenomas were more easily visualised by pituitary magnetic resonance imaging (MRI) in adult $(76 \%, 50 / 66)$ compared with paediatric $(55 \%, 21 / 38, P=0.045)$ CD with poorer concordance of imaging with surgical findings in children $(P=0.058)$. The incidence of ACTH lateralisation by bilateral simultaneous inferior petrosal sinus sampling was comparable in paediatric $(76 \%, 25 / 33)$ and adult $(79 \%, 46 / 58 ; P=0.95)$ patients with good surgical concordance in both $(82 \%$ paediatric and $79 \%$ adult). Cure rates by TSS were comparable, with a paediatric cure rate of $69 \%$.

Conclusion: Several features of paediatric CD are distinct: increased frequency of prepubertal CD in males, the different clinical presentation, the decreased presence of macroadenomas and the frequent absence of radiological evidence of an adenoma on MRI.
\end{abstract}

European Journal of Endocrinology 164 667-674

\section{Introduction}

Endogenous Cushing's syndrome (CS) is a rare disorder in children and is relatively uncommon in adults. The commonest cause of endogenous CS in all age groups is Cushing's disease $(\mathrm{CD})$, defined as hypercortisolaemia secondary to an ACTH-secreting pituitary corticotroph adenoma. At all ages, corticotroph microadenomas are the commonest cause of $\mathrm{CD}(1,2)$. Corticotroph macroadenomas occur in $\sim 10 \%$ of adult CD cases and are said to be even rarer in the paediatric age range $(3,4)$. CD accounts for $\sim 70 \%$ of adult-onset $(1,5)$ and $75-80 \%$ paediatric-onset endogenous CS (6-8). It is associated with significant morbidity in children and adults, so early diagnosis and treatment are important for optimal therapeutic outcome $(1,7)$.
At all ages, the clinical features of hypercortisolaemia are very variable and commonly cause diagnostic difficulties $(1,2)$. In addition, in paediatric CS, the presenting features may be subtle and can differ from those seen in adult patients $(2,7,9)$. It has been suggested that characteristic findings of paediatric CS include growth failure with associated weight gain, male predominance and abnormal pubertal development $(7,10-12)$. However, a detailed comparison of the clinical features at diagnosis between childhood- and adult-onset $\mathrm{CD}$ has not been previously performed.

The diagnosis of $\mathrm{CD}$ requires a series of standardised biochemical and radiological investigations (13). Despite the reported differences between adult- and childhood-onset $\mathrm{CD}$, the diagnostic criteria and investigation protocols for paediatric CS are generally derived 
from established adult practice. No single centre has analysed the differences between the biochemical and the radiological findings in the adult and paediatric CD patients. The primary aim of the treatment of $\mathrm{CD}$ is rapid normalisation of serum cortisol, and this is particularly important in children due to the adverse affects of prolonged hypercortisolaemia on growth and development $(7,14)$. Transsphenoidal surgery (TSS) with selective removal of the adenoma is the first-line treatment of choice for both childhood- and adultonset CD (2). The reported surgical success rates of TSS for $\mathrm{CD}$ are very variable in both adult and paediatric $\mathrm{CD}$ series $(1,15)$. These variations probably reflect the diversity of the populations of patients, the differences in neurosurgical centres and particularly the definitions used to define cure of CD. In children, TSS may be technically more difficult and requires treatment in a specialist centre by a neurosurgeon experienced in operating on children (16). A persistently undetectable serum cortisol $(<50 \mathrm{nmol} / \mathrm{l})$ within a week of surgery is generally considered the most reliable indicator of biochemical cure of CD (2). Using these strict criteria, we have been able to compare the cure rates of paediatric and adult CD by TSS performed by the same two experienced neurosurgeons.

\section{Subjects and patients}

\section{Patients}

Totally, 41 paediatric patients (26 males and 15 females; mean age $12.3 \pm 3.5$ years, range $5.7-17.8$ years) and 183 adult patients ( 39 males and 144 females; mean age $40.0 \pm 13.0$ years, range $18.0-95.0$ years) with CD were investigated and treated in the paediatric endocrinology and endocrinology divisions of St Bartholomew's and The Royal London Hospitals (London, UK) respectively. Paediatric and adolescent cases were diagnosed in our centre between 1983 and 2010, and data were collected on adult patients diagnosed with CD between 1960 and 2001. All subjects had clinical features of hypercortisolaemia, and diagnostic tests were performed according to the published paediatric and adult endocrinology departmental protocols $(8,17)$. All patients fulfilled standard diagnostic criteria for CD.

\section{Clinical features}

The clinical features were recorded at the time of diagnosis. Hypertension (HTN) in the paediatric subjects was defined as a diastolic or systolic blood pressure (BP) $>95$ th centile for age and sex on more than two occasions (18). Adult CD patients were considered hypertensive if there was a documented history of HTN with or without anti-hypertensive treatment, defined as a mean systolic BP >140 mmHg and/or diastolic BP $>90 \mathrm{mmHg}$ on three occasions (19).

\section{Pubertal staging and virilisation}

Puberty was staged at diagnosis in the paediatric patients according to Tanner's criteria $(20,21)$ and testicular volumes measured by a Prader orchidometer (22). True puberty was defined as testicular volumes $\geq 4 \mathrm{ml}$ or breast development $\geq$ stage 2 . Virilisation in the paediatric subjects was defined as an atypical advancement of pubic hair stage associated with prepubertal testicular volumes $(2-4 \mathrm{ml})$ in boys and prepubertal breast development (stage 1) in girls (10). Virilisation in the female adult subjects was defined as the presence of one or more clinical features of excessive androgen including temporal balding, deepening of the voice, hirsutism, hypertrichosis, decreased breast size, increased muscle mass, loss of female body contour (male escutcheon) and clitoral enlargement (23).

\section{Diagnosis of Cushing's disease}

CS was biochemically diagnosed on the basis of loss of serum cortisol circadian rhythm, i.e. an elevated sleeping midnight cortisol level of $>50 \mathrm{nmol} / \mathrm{l}$ and failure of serum cortisol to suppress to $<50 \mathrm{nmol} / \mathrm{l}$ during a low-dose dexamethasone suppression test (LDDST; $0.5 \mathrm{mg}, 6$ hourly for $48 \mathrm{~h}$ ) (17). Urinary free cortisol was not routinely measured. ACTH-dependent CS was based on a detectable $0900 \mathrm{~h}$ plasma ACTH level $(>10 \mathrm{ng} / \mathrm{l})$. The diagnosis was supported by suppression of serum cortisol to $<50 \%$ of baseline during a high-dose dexamethasone suppression test (HDDST; $2 \mathrm{mg}$ every $6 \mathrm{~h}$ for $48 \mathrm{~h}$ ) (17), although we no longer routinely use this test. For paediatric subjects weighing $<30 \mathrm{~kg}$, the dexamethasone dose given during the LDDST and HDDST were corrected for weight $(30 \mu \mathrm{g} / \mathrm{kg}$ per day and $120 \mu \mathrm{g} / \mathrm{kg}$ per day for $48 \mathrm{~h}$ respectively) (7). An exaggerated $(\geq 20 \%$ of baseline) response of serum cortisol during a CRH test (paediatric patients, $1 \mu \mathrm{g} / \mathrm{kg}$ and adult patients $100 \mu \mathrm{g}$ human-sequence CRH i.v.) also supported the diagnosis of $\operatorname{CD}(8,17,24)$. All patients had either histological evidence of a corticotroph adenoma or showed persisting clinical and biochemical remission after surgery and/or pituitary radiotherapy (RT).

\section{Pituitary imaging}

Preoperative pituitary computed tomography or magnetic resonance imaging (MRI) was performed in all patients, as described previously (25). In the paediatric patients, MR scanning was performed in 39 subjects following its introduction in 1985; 66 adult subjects had MR scanning performed between 1985 and 2001. Concordance of the microadenoma position by imaging compared with the findings at TSS was available for 47/66 adult patients. 


\section{Bilateral simultaneous inferior petrosal sinus sampling}

Bilateral simultaneous inferior petrosal sinus sampling (BSIPSS) was introduced in the investigation of adult patients in $1985(n=107)$ and in paediatric patients in $1986(n=33)$. The BSIPSS protocol has been described previously and was performed without sedation or systemic anaesthesia in all adult and all but two paediatric patients (25). Two very young paediatric patients aged 6.4 and 5.7 years required a general anaesthetic for the procedure. Intravenous $\mathrm{CRH}$ at a dose of $100 \mu \mathrm{g}(1 \mu \mathrm{g} / \mathrm{kg}$ for paediatric patients weighing $<30 \mathrm{~kg}$ ) was administered during BSIPSS and informed written consent was obtained from the patients, their parents or both, before the procedure.

\section{Interpretation of BSIPSS data}

A central to peripheral (IPS/P) or high internal jugular vein to peripheral $(\mathrm{HIJV} / \mathrm{P}) \mathrm{ACTH}$ ratio (the highest left or right IPS/HIJV value compared with the level simultaneously measured from the peripheral vein) of $\geq 2.0$ pre- or $\geq 3.0$ post-CRH was taken as indicative of central ACTH secretion $(17,26)$. Lateralisation of ACTH secretion was defined as an inter-petrosal sinus gradient (IPSG), whereas an HIJV gradient (HIJVG) after CRH administration of $\geq 1.4$ and an IPSG/HIJVG of $<1.4$ was suggestive of a midline lesion (17).

\section{Surgical treatment}

Totally, three paediatrics $(7 \%)$ underwent bilateral adrenalectomy. This was undertaken in the first paediatric subject in 1981, prior to the routine introduction of TSS, and 8 years later, TSS was performed due to the development of Nelson's syndrome (NS). Bilateral adrenalectomy was performed (as firstline therapy) in one patient aged 6.2 years because of extreme illness with respiratory failure and in another aged 14.7 years after two failed TSS procedures (the first at another centre and the second at our centre) due to acute psychosis induced by hypercortisolaemia. To date, these patients have not developed NS at 1 and 6 years post-adrenalectomy. In adult subjects, bilateral adrenalectomy was undertaken before the introduction of TSS, when TSS had failed to cure CD and RT did not adequately control hypercortisolaemia, or if RT was refused by patients for fertility reasons. Totally, 40 $(22 \%)$ adult patients had bilateral adrenalectomy in a single operation and six had a staged operation; one of these patients developed post-operative sepsis and 19 (48\% of adrenalectomised patients) patients developed NS (defined as increased pigmentation associated with rising levels of plasma ACTH, with or without evidence of an enlarging pituitary tumour). An additional four patients had total removal of one adrenal gland and subtotal removal of the other and another underwent autotransplantation of the adrenal tissue; interestingly, the latter developed NS. Three adult patients underwent unilateral adrenalectomy as a means of reducing cortisol levels.

TSS was performed in our centre in a total of 38 (93\%) paediatric patients (36 first-line and two secondline therapies, as described earlier) and 129 (70\%) adult patients (21 macroadenomas and 108 microadenomas) as first-line therapy as described previously (25). An additional four adult patients with macroadenomas underwent a transcranial approach. The localisation of the corticotroph microadenomas was based on the operation notes recorded by the surgeon at the time of transsphenoidal exploration. Post-operatively, serum cortisol was measured daily at $0900 \mathrm{~h}$, at least $12 \mathrm{~h}$ after the last dose of hydrocortisone. Cure of CD by TSS (in patients of all ages) was defined as an 'undetectable' $0900 \mathrm{~h}$ serum cortisol $(<50 \mathrm{nmol} / \mathrm{l})$. Adult patients not cured by TSS $(0900 \mathrm{~h}$ serum cortisol $>50 \mathrm{nmol} / \mathrm{l}$ post-operatively) were described as being in 'remission' if the post-operative serum cortisol was reduced to normality (mean cortisol on a 5-point day curve of 150-300 nmol/l). CD patients were considered 'relapsed' if there was a return of the clinical features in addition to biochemical evidence of CS (mean cortisol on a 5-point day-curve $>300 \mathrm{nmol} / \mathrm{l}$ and/or elevated sleeping midnight cortisol and/or the serum cortisol failed to suppress on a LDDST). Tissue obtained by TSS underwent histological and immunocytochemical analysis. Results of the histopathological analysis were available in 38 paediatric and 129 adult patients.

\section{Statistical analysis}

Values are stated as mean \pm s.D. Qualitative data and proportions were compared using a $\chi^{2}$ analysis and significance was defined as $P<0.05$. MedCalc (Version 10.1.5.0, Windows 98/NT/Me/2000/XP/Vista) was used.

\section{Results}

\section{Sex incidence, puberty and virilisation at diagnosis in paediatric and adult-onset CD}

As previously reported, paediatric $\mathrm{CD}$ had a male predominance $(63 \%)$, whereas females dominated the adult CD group $(79 \%)(1,11)$. This difference in sex distribution was highly significant $(P<0.0001)$. Totally, 21 paediatric patients were prepubertal (15 males and 6 females; mean age $10.3 \pm 2.9$ years, range 5.7-14.1 years, $71 \%$ male predominance) and 20 were pubertal (11 males and 9 females; mean age $14.7 \pm 2.2$ years, range 9.4-17.8 years). Virilisation was very common $(76 \%, 16 / 21)$ in the prepubertal patients $(11$ males and 5 females, mean age $10.5 \pm 2.8$, including $5 / 6$ prepubertal females), while virilisation features were present in $22 \%$ of the female adult CD patients $(P<0.0001)$. 


\section{Clinical features at diagnosis in paediatric and adult-onset CD}

Weight gain was present in all but one of the paediatric subjects (mean body mass index SDS at diagnosis $2.7 \pm 1.6$; range $0.0-9.2$ ) in contrast to $65 \%$ of the adult subjects $(P=0.001$; Table 1$)$. Growth failure was evident in all the paediatric subjects (mean height SDS at diagnosis $-1.8 \pm 1.3$; range -1.2 to -4.2 ). All paediatric patients reported facial changes compared with $81 \%$ of the adults $(P=0.01)$. Fatigue and emotional lability/depression were commoner findings in paediatric compared with adult subjects $(P<0.0001$ and $P=0.006$ respectively). HTN was the most common additional feature in adult patients $(77 \%)$ but was less common in paediatric patients $(49 \%, P=0.0009)$. Interestingly, features of hypercortisolaemia including striae and acne were more likely to be present in older rather than younger children in our series (Table 1).

\section{Low- and high-dose dexamethasone suppression tests}

The majority of paediatric and adult CD patients failed to suppress serum cortisol levels during a LDDST; data were available for 38 paediatric and 194 adult CD subjects. There was no significant difference $(P=0.86)$ between the number of paediatric $(8 \%, 3 / 38)$ and adult $(7 \%$, 14/194) CD patients who suppressed their baseline serum cortisol to $<50 \mathrm{nmol} / \mathrm{l}$. Data were available for HDDSTs performed in 28 paediatric and 187 adult CD subjects: the mean suppression of the baseline serum cortisol at $48 \mathrm{~h}$ during HDDST was not significantly different $(80 \%$ in the paediatric and $72 \%$ in the adult $\mathrm{CD}$ patients; $P=0.51)$. Additionally, $28 / 187(15 \%)$ adult and $2 / 28(7 \%)$ paediatric patients did not suppress the serum cortisol to $<50 \%$ baseline during HDDST.

\section{The CRH test}

The administration of i.v. CRH induced an increase in serum cortisol in the paediatric $(n=39)$ and adult $(n=123)$ CD patients. The response was significantly greater in the paediatric (mean change +105\%) compared with the adult patients (mean change $+54 \%$ ) $(P<0.0001)$. A slightly higher proportion of paediatric CD patients $(92 \%, 36 / 39)$ exhibited a $20 \%$ or more increase in serum cortisol during a CRH test compared with the adult patients $(81 \%, 99 / 123)$, but this was not statistically significant $(P=0.17)$.

\section{Identification of the corticotroph adenoma by pituitary MRI and concordance with the surgical findings}

MR images were obtained in a total of 39 paediatric and 66 adult patients (Table 2). Pituitary MRI identified significantly less macroadenomas in paediatric $2 \%$ $(1 / 41)$ compared with $15 \%(28 / 183)$ of adult patients $(P=0.04)$. The appearances were consistent with the presence of a microadenoma in 55\% (21/38) of paediatric compared with $76 \%(50 / 66)$ of adult patients, this difference being significant $(P=0.045)$. The percentage concordance of the microadenoma position by imaging compared with the findings at TSS was also lower in children $(34 \%, 13 / 38)$ compared with adults $(57 \%, 27 / 47)(P=0.058)$.

\section{Confirmation of central ACTH secretion by BSIPSS}

Sampling for ACTH was successfully undertaken from both IPS in $88 \%(29 / 33)$ paediatric and $64 \%(67 / 104$, $P=0.01$ ) adult patients, bilateral sampling was obtained from the HIJV in a further four (12\%) paediatric and 19 $(18 \%, P=0.69)$ adult patients (Tables 3 and 4$)$. In the remaining $19(18 \%)$ adult patients, sampling from one IPS and the contralateral HIJV was performed.

In the patients where samples were obtained from one or both IPS, the central to peripheral (IPS/P) ratio preCRH of $>2$ was observed in a similar proportion of $76 \%$ $(22 / 29)$ paediatric and $72 \%(61 / 85)$ adult patients $(P=0.85)$. After $\mathrm{CRH}$ stimulation, an IPS/P ratio of $>3$

Table 1 Clinical features and age at diagnosis in paediatric and adult-onset CD.

\begin{tabular}{|c|c|c|c|c|}
\hline \multirow[b]{2}{*}{ Clinical feature } & \multirow{2}{*}{$\begin{array}{l}\text { Adult CD subjects }(n=183) \\
\qquad n \text { with symptom } \\
\text { or sign }(\%)\end{array}$} & \multicolumn{2}{|c|}{ Paediatric CD subjects $(n=41)$} & \multirow[b]{2}{*}{$P$ value } \\
\hline & & $\begin{array}{l}n \text { with symptom } \\
\text { or sign }(\%)\end{array}$ & $\begin{array}{l}\text { Mean age } \pm \text { s.D. } \\
\quad \text { (years) }\end{array}$ & \\
\hline Weight gain & $119(65)$ & $40(98)$ & $12.3 \pm 3.5$ & 0.001 \\
\hline Weight loss & $8(4)$ & $1(2)$ & (age 13.2) & 0.87 \\
\hline Facial changes & $154(81)$ & $41(100)$ & $12.3 \pm 3.5$ & 0.01 \\
\hline Fatigue & $48(26)$ & $25(61)$ & $11.6 \pm 3.6$ & $<0.0001$ \\
\hline Virilisation & 41 (22) & $16 / 21(76)$ & $10.5 \pm 2.8$ & $<0.0001$ \\
\hline Hirsutism & $125(68)$ & $24(59)$ & $12.6 \pm 3.3$ & 0.37 \\
\hline Emotional lability/depression & $75(41)$ & $24(59)$ & $11.8 \pm 3.1$ & 0.006 \\
\hline Headaches & $57(31)$ & $21(51)$ & $12.7 \pm 3.2$ & 0.02 \\
\hline Striae & $73(40)$ & $20(49)$ & $14.2 \pm 2.6$ & 0.38 \\
\hline Hypertension & $140(77)$ & $20(49)$ & $11.8 \pm 3.5$ & 0.0009 \\
\hline Acne & $49(27)$ & $18(44)$ & $13.9 \pm 2.2$ & 0.05 \\
\hline
\end{tabular}


Table 2 Pituitary MRI and concordance with the surgical findings in paediatric and adult-onset CD.

\begin{tabular}{clll}
\hline & $\begin{array}{l}\text { Macroadenomas } \\
\text { on MR/CT image } \\
(n(\%))\end{array}$ & $\begin{array}{l}\text { Microadenomas } \\
\text { on MR image } \\
(n(\%))\end{array}$ & $\begin{array}{l}\text { Concordance } \\
\text { of image with } \\
\text { surgery }(\%)\end{array}$ \\
\hline $\begin{array}{c}\text { Paediatric } \\
\text { patients }\end{array}$ & $1 / 41(2)$ & $21 / 38(55)$ & $13 / 38(34)$ \\
$\begin{array}{c}\text { Adult } \\
\text { patients }\end{array}$ & $28 / 183(15)$ & $50 / 66(76)$ & $27 / 47(57)$ \\
$P$ value & 0.045 & 0.03 & 0.058 \\
\hline
\end{tabular}

was observed in $86 \%(25 / 29)$ paediatric and $95 \%$ $(81 / 85)$ adult patients $(P=0.23)$. Where ACTH sampling was undertaken bilaterally from the HIJV, an $\mathrm{HIJV} / \mathrm{P}$ ratio of $>2$ pre- or post-CRH was observed in a similar proportion of paediatric $(75 \%, 3 / 4)$ and adult patients $(58 \%, 11 / 19)(P=0.94)$.

\section{Lateralisation of ACTH secretion by BSIPSS and concordance with the surgical findings}

A similar incidence of lateralisation of ACTH secretion (IPSG > 1.4) was observed in $76 \%(25 / 33)$ paediatric and $79 \%(46 / 58)$ adult patients ( $P=0.94$; Tables 3 and 4$)$. The percentage concordance of the microadenoma position by BSIPSS compared with the findings at TSS was high in both the paediatric $82 \%(27 / 33)$ and the adult $79 \%(46 / 58)$ patients $(P=0.61)$. In the paediatric group, bilateral sampling from the HIJVs correctly predicted the tumour position in all cases: $75 \%(3 / 4)$ demonstrated ACTH lateralisation, which was confirmed during TSS, whereas the other patient who obtained an HIJVG of $<1.4$ was found to have a midline tumour.

\section{Histopathological findings}

After TSS, a corticotroph adenoma was histologically confirmed in a similar proportion of paediatric $(63 \%$, $24 / 38)$ and adult $(70 \%, 90 / 129)$ patients $(P=0.53)$.

\section{Cure rate of TSS and outcome}

Macroadenomas The single paediatric patient with a macroadenoma had an undetectable serum cortisol 5 days post-TSS, but 9 months later, residual tumour was noted on the repeat MR scan and there was evidence of biochemical relapse (sleeping midnight cortisol $105 \mathrm{nmol} / \mathrm{l}$; Table 5). Of the 28 adult patients with macroadenomas, 25 were treated by neurosurgical approach as first-line treatment (21 TSS and four craniotomy); eight were cured and a further four patients were in remission giving an initial cure/remission rate of 12/25 (48\%). Relapse occurred in one and three of the adult patients cured and in remission after neurosurgery respectively, giving an overall cure/remission rate of $8 / 25(32 \%)$.

Microadenomas of 35 paediatric corticotroph adenomas, 24 (69\%; 12 females and 12 males, median 14.0 years; range 5.7-16.7) and 55/108 (51\%) adult corticotroph adenomas were cured $(P=0.10)$. A further 29 adult patients were in remission giving an initial cure/remission rate of 84/108 (78\%). Relapse occurred in nine of the cured adult patients and nine of the adult patients in remission after neurosurgery respectively, giving an overall cure/remission rate of 66/108 (61\%). The cure rate in the paediatric patients who underwent BSIPSS preoperatively was higher $(73 \%, 24 / 33)$ than those who did not undergo the procedure, although this was not statistically significant $(P=0.5)$.

\section{Discussion}

CD is a rare disorder, which if left untreated results in significant morbidity, mortality and a reduction in quality of life (27). The diagnosis and management of CD presents a considerable challenge, even in experienced units (5). CD in childhood and adolescence poses additional difficulties, as it is particularly rare. It is also especially important that definitive treatment of paediatric CD is initiated early to limit the adverse effects on growth, pubertal development and body composition $(9,10,28)$. Several studies on paediatric CD have been published, but there are no reported detailed comparisons between the features of childhood- and adult-onset CD. A detailed characterisation of paediatric CD should assist the diagnostic process by highlighting the common clinical and biochemical features of this rare disorder, as well as any possible distinctive features in the paediatric age range. It is also possible that investigation and treatment protocols that are usually derived from the studies of adult patients can be rationalised for the management of children with suspected CD.

Table 3 Bilateral HIJV sampling and concordance with the surgical findings in paediatric and adult-onset CD.

\begin{tabular}{lllll}
\hline & Bilateral HIJV \\
sampling $(n(\%))$ & $\begin{array}{l}\text { HIJV/P ratio pre- or } \\
\text { post-CRH }>\mathbf{2}(n(\%))\end{array}$ & $\begin{array}{l}\text { Lateralisation } \\
(\text { HIJVG }>1.4)(n(\%))\end{array}$ & $\begin{array}{l}\text { Concordance } \\
\text { with surgery } \\
(\%)\end{array}$ \\
\hline Paediatric patients $(n=33)$ & $4 / 33(12)$ & $3 / 4(75)$ & $3 / 4(75)$ & $4 / 4(100)$ \\
Adult patients $(n=104)$ & $19 / 104(18)$ & $11 / 19(58)$ & - & - \\
$P$ value & 0.69 & 0.94 & - & - \\
\hline
\end{tabular}


Table 4 BSIPSS for ACTH and concordance with the surgical findings in paediatric and adult-onset CD.

\begin{tabular}{llllll}
\hline & BSIPSS & $\begin{array}{l}\text { IPS/P ratio } \\
\text { pre-CRH }>2 \\
(n(\%))\end{array}$ & $\begin{array}{l}\text { IPS/P ratio } \\
\text { post-CRH }>2 \\
(n(\%))\end{array}$ & $\begin{array}{l}\text { Lateralisation } \\
(\text { IPSG }>1.4) \\
(n(\%))\end{array}$ & $\begin{array}{l}\text { Concordance } \\
\text { with surgery } \\
(\%)\end{array}$ \\
\hline $\begin{array}{lllll}\text { Paediatric patients }(n=33) \\
\text { Adult patients }(n=104)\end{array}$ & $29 / 33(88)$ & $22 / 29(76)$ & $25 / 29(86)$ & $25 / 33(76)$ & $27 / 33(82)$ \\
$P$ value & $67 / 104(64)$ & $61 / 85(72)$ & $\begin{array}{l}81 / 85(95) \\
0.23\end{array}$ & $\begin{array}{l}46 / 58(79) \\
0.94\end{array}$ & 0.61 \\
\hline
\end{tabular}

The prevalence of clinical signs and symptoms associated with CS have been well documented in many large adult series $(17,29,30)$. In contrast, the detailed clinical features of paediatric CS have been reported in only one large series (7) and in our own smaller series in 1995 (14). In our current, much larger series, a change in facial appearance was universal in our paediatric patients and reported in $81 \%$ of the adult patients. Suppression of linear growth associated with weight gain is a well-documented characteristic of hypercortisolaemia in childhood $(3,4,7)$ and was evident in our paediatric cohort.

Weight loss has been recognised as a presenting clinical feature of adult CD (30) but has not previously been reported in paediatric CD. This atypical appearance may be explained by very mild or cyclical hypercortisolaemia and is also occasionally seen in very active patients. We and others have reported abnormal virilisation and hirsutism in paediatric $\mathrm{CD}$ patients $(7,10)$. This is also well recognised in adult female CD due to excessive androgen secretion $(17,31)$ but appears to be more common in childhood. Pubertal delay or arrest is frequently seen in paediatric patients caused by suppression of the hypothalamic-pituitarygonadal axis by hypercortisolaemia and is a characteristic feature of paediatric CD (10). Other frequently recognised features of hypercortisolaemia in adult patients include headaches, striae and acne (17); interestingly, these were more likely to be present in older rather than younger children in our study. HTN is a common presenting feature in adult CS $(17,30)$, but in our study, it was less prevalent in children.
Commonly reported symptoms in childhood were a change in facial appearance, weight gain, lethargy and emotional lability, which appear to be somewhat less reported in adult patients. However, the retrospective nature of this study may compromise the validity of some of the reported clinical features and may limit the conclusions that can be drawn.

In adult $\mathrm{CD}$, it is recognised that $\sim 8 \%$ patients retain the ability to suppress serum cortisol normally during the standard LDDST (32). This has not previously been reported in children and was evident in a similar proportion $(7 \%)$ of our paediatric patients. The CRH test supports the diagnosis of $\mathrm{CD}$ in all ages and it was interesting that children exhibited a more exuberant cortisol response. The proportion of children with $\mathrm{CD}$ who had a $<20 \%$ increase of serum cortisol to i.v. CRH was lower compared with the adult patients, although this failed to achieve statistical significance. Our data suggest that paediatric corticotroph adenomas respond more readily to $\mathrm{CRH}$ administration, and this should enhance the utility of the CRH test in paediatric practice to differentiate $\mathrm{CD}$ from an ectopic source.

A striking difference was the lower percentage of adenomas that were detectable on pituitary imaging in children compared with adults. Paediatric ACTHsecreting microadenomas are frequently smaller, with $70 \%$ having a diameter of $\leq 5.0 \mathrm{~mm}(33,34)$. This difference could be explained by the limited spatial resolution of MRI, i.e. small lesions within a small pituitary gland are less conspicuous and it is clear that pituitary MRI alone cannot be relied upon for the diagnosis of paediatric $\mathrm{CD}$. Bilateral petrosal sinus

Table 5 Surgical treatment and outcome.

\begin{tabular}{lllllll}
\hline & $\begin{array}{l}\text { First-line TSS } \\
\text { or craniotomy } \\
(n)\end{array}$ & Cure (\%) & Remission (\%) & $\begin{array}{l}\text { Initial cure/ } \\
\text { remission } \\
\text { rate (\%) }\end{array}$ & $\begin{array}{l}\text { Relapse } \\
\text { rate (\%) }\end{array}$ & $\begin{array}{l}\text { Overall TSS } \\
\text { cure/remission } \\
\text { rate }(\%)\end{array}$ \\
\hline $\begin{array}{l}\text { Paediatric CD (41) } \\
\text { Microadenoma (40) }\end{array}$ & TSS (36) & $24 / 35(69)$ & - & - & - & $24 / 35(69)$ \\
$\begin{array}{l}\text { Macroadenoma (1) } \\
\text { Adult CD (183) }\end{array}$ & TSS (1) & - & - & - & $1 / 1(100)$ & 0 \\
Microadenoma (155) & TSS (108) & $55 / 108(51)$ & $29 / 108(27)$ & $84 / 108(78)$ & $18 / 108(17)$ & $66 / 108(61)$ \\
Macroadenoma (28) & TSS (21) & $8 / 25(32)$ & $4 / 25(16)$ & $12 / 25(48)$ & $3 / 25(12)$ & $8 / 25(32)$ \\
\hline
\end{tabular}

Cure, post-operative serum cortisol $<50 \mathrm{nmol} / /$; remission, post-operative mean serum cortisol on a 5-point day curve of $150-300 \mathrm{nmol} / /$; relapse, return of the clinical features in addition to biochemical evidence of Cushing's syndrome (mean cortisol on a 5-point day curve $>300 \mathrm{nmol} / \mathrm{l}$ and/or elevated sleeping midnight cortisol and/or the serum cortisol failed to suppress on a LDDST). 
sampling in children has been reported in three paediatric $\mathrm{CD}$ series, including our own $(3,7,25)$. In our series, successful catheterisation of the IPS was achieved in a favourable and similar proportion of children compared with adults, and the procedure correctly identified a pituitary source of ACTH in the majority of patients. Rates of lateralisation of ACTH and the percentage concordance of BSIPSS with surgical location were comparable in children and adults. As described previously in adult $\mathrm{CD}$, jugular venous sampling correctly predicted the tumour position in our paediatric group and may be a useful alternative where IPSS is technically difficult (35). BSIPSS was tolerated in all but the youngest patients without sedation or general anaesthesia, and our results show a trend for a greater cure rate following its introduction.

The reported surgical success rates for CD are very variable, depending on the definition of cure that is used. In our centre, we use the very stringent definition for cure of an undetectable serum cortisol in the immediate post-operative period. The cure rate of $69 \%$ in children compares very favourably with other groups (36-38), and although the strictly defined cure rate is lower in the adult group, the initial remission rate of $78 \%$ in adult $\mathrm{CD}$ equals or exceeds other published series $(1,2)$. In all ages, the cure rate by TSS increased over time with the introduction of preoperative BSIPSS and as surgical experience and techniques improved. Our adult group was sampled over a longer time period than the paediatric population, and it is likely that the cure rate will be higher in more recently treated patients. Certainly, in experienced hands, the response to surgery appears to be at least as good in childhood as in adult patients. ACTH-secreting macroadenomas are reported to be refractory to surgical treatment, and consistent with this, the surgical cure rate of macroadenomas is low in both the groups (39).

In conclusion, male predominance is characteristic of CD in childhood. Several clinical features are distinct in childhood-onset $\mathrm{CD}$, and in contrast, more florid features of hypercortisolaemia are relatively rare in young children. The CRH test shows a more exuberant response in paediatric patients, but the frequent absence of an adenoma on MRI makes such imaging an unreliable diagnostic test in children. In an experienced centre, BSIPSS is a safe and well-tolerated procedure and has been of considerable clinical importance in our cohort of patients, with cure rates comparable to adult patients.

\section{Declaration of interest}

The authors declare that there is no conflict of interest that could be perceived as prejudicing the impartiality of the research reported.

\section{Funding}

This research did not receive any specific grant from any funding agency in the public, commercial or not-for-profit sector.

\section{References}

1 Newell-Price J, Bertagna X, Grossman AB \& Nieman LK. Cushing's syndrome. Lancet 2006367 1605-1617. (doi:10.1016/S01406736(06)68699-6)

2 Biller BM, Grossman AB, Stewart PM, Melmed S, Bertagna X, Bertherat J, Buchfelder M, Colao A, Hermus AR, Hofland LJ, Klibanski A, Lacroix A, Lindsay JR, Newell-Price J, Nieman LK, Petersenn S, Sonino N, Stalla GK, Swearingen B, Vance ML, Wass JAH \& Boscaro M. Treatment of adrenocorticotropindependent Cushing's syndrome: a consensus statement. Journal of Clinical Endocrinology and Metabolism 200893 2454-2462. (doi:10.1210/jc.2007-2734)

3 Batista D, Gennari M, Riar J, Chang R, Keil MF, Oldfield EH \& Stratakis CA. An assessment of petrosal sinus sampling for localization of pituitary microadenomas in children with Cushing disease. Journal of Clinical Endocrinology and Metabolism 200691 221-224. (doi:10.1210/jc.2005-1096)

4 Leinung MC, Kane LA, Scheithhauer BW, Carpenter PC \& Zimmerman D. Long term follow-up of transsphenoidal surgery for the treatment of Cushing's disease in childhood. Journal of Clinical Endocrinology and Metabolism 199580 2475-2479. (doi:10.1210/jc.80.8.2475)

5 Nieman LK \& Ilias I. Evaluation and treatment of Cushing's syndrome. American Journal of Medicine 2005118 1340-1346. (doi:10.1016/j.amjmed.2005.01.059)

6 Magiakou MA \& Chrousos GP. Cushing's syndrome in children and adolescents: current diagnostic and therapeutic strategies. Journal of Clinical Investigation 200225 181-194.

7 Magiakou MA, Mastorakos G, Oldfield EH, Gomez MT, Doppman JL, Cutler GB, Nieman LK \& Chrousos GP. Cushing's syndrome in children and adolescents, presentation, diagnosis and therapy. New England Journal of Medicine 1994331 629-636. (doi:10.1056/NEJM199409083311002)

8 Storr HL, Chan LF, Grossman AB \& Savage MO. Paediatric Cushing's syndrome: epidemiology, investigation and therapeutic advances. Trends in Endocrinology and Metabolism $2007 \mathbf{1 8}$ 167-174. (doi:10.1016/j.tem.2007.03.005)

9 Savage MO, Lienhardt A, Lebrethon MC, Johnston LB, Huebner A, Grossman AB, Afshar F, Plowman PN \& Besser GM. Cushing's disease in childhood: presentation, investigation, treatment and long-term outcome. Hormone Research 200155 24-30. (doi:10.1159/000063459)

10 Dupuis CC, Storr HL, Perry LA, Ho JTF, Ahmed L, Ong KK, Dunger DB, Monson JP, Grossman AB, Besser GM \& Savage MO. Abnormal puberty in paediatric Cushing's disease: relationship with adrenal androgen, sex hormone binding globulin and gonadotrophin concentrations. Clinical Endocrinology 200766 838-843. (doi:10.1111/j.1365-2265.2007.02822.x)

11 Storr HL, Isidori AM, Monson JP, Besser GM, Grossman AB \& Savage MO. Pre-pubertal Cushing's disease is more common in males, but there is no increase in severity at diagnosis. Journal of Clinical Endocrinology and Metabolism 200489 3818-3820. (doi:10.1210/jc.2003-031531)

12 Batista D, Riar J, Keil M \& Stratakis CA. Diagnostic tests for children who are referred for the investigation of Cushing syndrome. Pediatrics 2007120 575-586. (doi:10.1542/peds. 2006-2402)

13 Nieman LK, Biller BM, Findling JW, Newell-Price J, Savage MO, Stewart PM \& Montori V. The diagnosis of Cushing's syndrome: an Endocrine Society Clinical Practice Guideline. Journal of Clinical Endocrinology and Metabolism 200893 1526-1540. (doi:10.1210/jc.2008-0125)

14 Weber A, Trainer PJ, Grossman AB, Afshar F, Medbak S, Perry LA, Plowman PN, Rees LH, Besser GM \& Savage MO. Investigation, management and therapeutic outcome in 12 cases of childhood and adolescent Cushing's syndrome. Clinical Endocrinology 1995 43 19-28. (doi:10.1111/j.1365-2265.1995.tb01888.x)

15 Storr HL, Afshar F, Matson M, Sabin I, Davies KM, Evanson J, Plowman PN, Besser GM, Monson JP, Grossman AB \& Savage MO. 
Factors influencing cure by transsphenoidal selective adenomectomy in paediatric Cushing's disease. European Journal of Endocrinology 2005152 825-833. (doi:10.1530/eje.1.01921)

16 Joshi SM, Hewitt RJD, Storr HL, Rejzajooi K, Ellamushi H, Grossman AB, Savage MO \& Afshar F. Cushing's disease in children and adolescents: twenty years experience in a single neurosurgical centre. Neurosurgery 200557 281-285. (doi:10. 1227/01.NEU.0000166580.94215.53)

17 Newell-Price J, Trainer PJ, Besser GM \& Grossman AB. The diagnosis and differential diagnosis of Cushing's and peudo-Cushing's states. Endocrine Reviews 199919 647-672. (doi:10.1210/er.19.5.647)

18 Falkner B \& Daniels SR. Summary of the Fourth Report on the Diagnosis, Evaluation, and Treatment of High Blood Pressure in Children and Adolescents. Hypertension $2004 \mathbf{4 4} 387-388$. (doi:10.1161/01.HYP.0000143545.54637.af)

19 Chobanian AV, Bakris GL, Black HR, Cushman WC, Green LA, Izzo JL Jr, Jones DW, Materson BJ, Oparil S, Wright JT Jr \& Roccella EJ. Seventh Report of the Joint National Committee on Prevention, Detection, Evaluation, and Treatment of High Blood Pressure. Hypertension 200342 1206-1252. (doi:10.1161/01. HYP.0000107251.49515.c2)

20 Marshall WA \& Tanner JM. Variation in the pubertal changes in girls. Archives of Disease in Childhood 196945 291-303. (doi:10. 1136/adc.44.235.291)

21 Marshall WA \& Tanner JM. Variation in the pubertal changes in boys. Archives of Disease in Childhood 1970 45 13-23. (doi:10.1136/adc.45.239.13)

22 Prader A. Testicular size: assessment and clinical importance. Triangle 19667 240-243.

23 Yildiz BO. Diagnosis of hyperandrogenism: clinical criteria. Best Practice and Research. Clinical Endocrinology and Metabolism 2006 20 167-176. (doi:10.1016/j.beem.2006.02.004)

24 Isidori AM, Kaltsas GA, Mohammed S, Morris DG, Jenkins P, Chew SL, Monson JP, Besser GM \& Grossman AB. Discriminatory value of the low-dose dexamethasone suppression test in establishing the diagnosis and differential diagnosis of Cushing's syndrome. Journal of Clinical Endocrinology and Metabolism 2003 88 5299-5306. (doi:10.1210/jc.2003-030510)

25 Lienhardt A, Grossman AB, Dacie JE, Evanson J, Huebner A, Afshar F, Plowman PN, Besser GM \& Savage MO. Relative contributions of inferior petrosal sinus sampling and pituitary imaging in the investigation of children and adolescents with ACTH-dependent Cushing's syndrome. Journal of Clinical Endocrinology and Metabolism 200186 5711-5714. (doi:10. $1210 /$ jc.86.12.5711)

26 Kaltsas GA, Giannulis MG, Newell-Price JDC, Dacie JE, Thakkar C, Afshar F, Monson JP, Grossman AB, Besser GM \& Trainer PJ. A critical analysis of the value of simultaneous inferior petrosal sinus sampling in Cushing's disease and the occult ectopic adrenocorticotropin syndrome. Journal of Clinical Endocrinology and Metabolism 199984 487-492. (doi:10.1210/jc.84.2.487)

27 Linsay JR, Nansel T, Baid S, Gumowski J \& Nieman LK. Long-term impaired quality of life in Cushing's syndrome despite initial improvement after surgical remission. Journal of Clinical Endocrinology and Metabolism 200691 447-453. (doi:10.1210/ jc.2005-1058)

28 Davies JH, Storr HL, Davies KM, Monson JP, Besser GM, Afshar F, Plowman PN, Grossman AB \& Savage MO. Final adult height and body mass index after cure of paediatric Cushing's disease. Clinical Endocrinology 200562 466-472. (doi:10.1111/j.1365-2265. 2005.02244.x)

29 Findling JW \& Raff H. Cushing's syndrome: important issues in diagnosis and management. Journal of Clinical Endocrinology and Metabolism 200691 3746-3753. (doi:10.1210/jc.2006-0997)

30 Boscaro M \& Arnaldi G. Approach to the patient with possible Cushing's syndrome. Journal of Clinical Endocrinology and Metabolism 200994 3121-3131. (doi:10.1210/jc.2009-0612)

31 Arnaldi G, Angeli A, Atkinson AB, Bertagna X, Cavagnini F, Chrousos GP, Fava GA, Findling JW, Gaillard RC, Grossman AB, Kola B, Lacroix A, Mancini T, Mantero F, Newell-Price J, Nieman LK, Sonino N, Vance ML, Giustina A \& Boscaro M. Diagnosis and complications of Cushing's syndrome: a consensus statement. Journal of Clinical Endocrinology and Metabolism 2003 88 5593-5602. (doi:10.1210/jc.2003-030871)

32 Findling JW, Raff $\mathrm{H} \&$ Aron DC. The low-dose dexamethasone suppression test: a reevaluation in patients with Cushing's syndrome. Journal of Clinical Endocrinology and Metabolism 2004 89 1222-1226. (doi:10.1210/jc.2003-030207)

33 Styne DM, Grumbach MM, Kaplan SL, Wilson CB \& Conte FA. Treatment of Cushing's disease in childhood and adolescence by transsphenoidal microadenomectomy. New England Journal of Medicine 1984310 889-893. (doi:10.1056/NEJM1984040 53101405)

34 Fahlbusch R, Honegger J, Buchfelder M, Savage MO, Bourguinon JP \& Grossman AB. Neurosurgical management of Cushing's disease in children. In Frontiers in Paediatric Endocrinology, pp 68-72. Oxford: Blackwell Scientific Publications, 1994.

35 Ilias I, Chang R, Pacak K, Oldfield EH, Wesley R, Doppman J \& Nieman LK. Jugular venous sampling: an alternative to petrosal sinus sampling for the diagnostic evaluation of adrenocorticotropic hormone-dependent Cushing's syndrome. Journal of Clinical Endocrinology and Metabolism 200489 3795-3800. (doi:10. 1210/jc.2003-032014)

36 Acharya SV, Gopal RA, Goerge J, Menon PS, Bandgar TR \& Shah NS. Radiotherapy in paediatric Cushing's disease: efficacy and long term follow up of pituitary function. Pituitary 201013 293-297. (doi:10.1007/s11102-010-0231-x)

37 de Oliveira RS, de Castro M, Antonini SR, Martinelli CE Jr, Moreira AC \& Machado HR. Surgical management of paediatric Cushing's disease: an analysis of 15 consecutive cases at a specialized neurosurgical centre. Arquivos Brasileiros de Endocrinologia e Metabologia 201054 17-23.

38 Dyer EH, Civit T, Visot A, Delalande O \& Derome P. Transsphenoidal surgery for pituitary adenomas in children. Neurosurgery 199434 207-212 (discussion 212). (doi:10.1227/00006123199402000-00001)

39 Woo YS, Isidori AM, Wat WZ, Kaltsas GA, Afshar F, Sabin I, Jenkins PJ, Monson JP, Besser GM \& Grossman AB. Clinical and biochemical characteristics of adrenocorticotropin-secreting macroadenomas. Journal of Clinical Endocrinology and Metabolism 200590 4963-4969. (doi:10.1210/jc.2005-0070)

Received 1 February 2011

Accepted 10 February 2011 